\title{
Physical and Mechanical Properties of the Wood Used in Indigenous Housing of the Tuchín Township, Department of Cordoba, Colombia*
}

\section{Propiedades Físico-Mecánicas de Maderas Utilizadas en la Construcción de Viviendas Indígenas del Municipio de Tuchín Departamento de Córdoba}

DOI:http://dx.doi.org/10.17981/ingecuc.11.1.2015.10

Research Article - Reception Date: August 21, 2014 - Acceptance Date: February 24, 2015

Carmen Sofía Echenique Racero

Civil Engineering Student, Universidad Pontificia Bolivariana. Montería (Colombia). carmen.echeniquer@hotmail.com

Barley Irene Banda Nieto

Civil Engineering Student, Universidad Pontificia Bolivariana. Montería (Colombia).barle27@hotmail.com

José Rodrigo Hernández Ávila

Master in Structures and Construction, Universidad de Sucre. Sincelejo (Colombia). jose.hernandez@unisucre.edu.co

To cite this paper:

C. S. Echenique Racero, B. I. Banda Nieto and J. R. Hernández Ávila, "Physical and Mechanical Properties of the Wood Used in Indigenous Housing of the Tuchín Township, Department of Cordoba, Colombia" INGE CUC, vol. 11, no. 1, pp. 99-108, 2015. DOI: http://dx.doi.org/10.17981/ingecuc.11.1.2015.10

\begin{abstract}
Indigenous communities have long used the natural resources around them. Most of the traditional construction techniques used are the result of empirical knowledge and of their own and humble style coming to life through craftsmanship. The physical and mechanical properties of the different types of wood used in the construction of indigenous households in the municipality of Tuchín are analyzed in this paper taking into account their features, uses, and renown importance. To obtain the information regarding the properties, the different uses bestowed to the various tree species were studied; in order to do so, trials to defectless wood samples were performed in accordance with established rules. The properties of moisture content, anhydrous density, basic density, basic specific gravity, total and partial contractions -radial, tangential, and volumetric, and parallel and perpendicular compression stress were determined.
\end{abstract}

Keywords-- Lumber, Housing, Indigenous, Tuchín, Physical properties, Mechanical properties, Poisson module, Compression, Oak.

\begin{abstract}
Resumen-- Las comunidades indígenas por mucho tiempo han utilizado los recursos naturales que los rodean. La mayoría de las técnicas constructivas tradicionales que utilizan son resultado del conocimiento empírico con estilo propio y sencillo, utilizando mano de obra artesanal. Es necesario conocer las propiedades físico-mecánicas de los diferentes tipos de maderas utilizadas en la construcción de las viviendas indígenas en el Municipio de Tuchín teniendo en cuenta sus características, sus usos y su importancia internacional. Para la obtención de estas propiedades se investigó sobre los diversos usos dados a la madera de diversas especies forestales; se realizaron ensayos a muestras de madera libres de defectos de acuerdo con las normas establecidas. Se determinaron las propiedades de contenido de humedad, densidad anhidra, densidad básica, peso específico básico, contracciones totales y parciales -volumétricas, radiales y tangenciales, y resistencia a la compresión paralela y perpendicular.
\end{abstract}

Palabras claves-- Madera, viviendas, indígena, Tuchín, propiedades físicas, mecánicas, módulo de Poisson, compresión, roble.

"Research paper deriving from the research Project "Modelación Estructural de Viviendas Indígenas del Municipio de Tuchín Departamento de Córdoba”. Funded by Universidad Pontificia Bolivariana y Universidad de Sucre. Starting date: July 2013 . Ending date: September 2014. 


\section{INTRODUCTION}

Concrete and steel are the most popular materials in construction around the world. Lumber was relegated to minor structural uses and it is most valued for finishings, furniture, or decorative elements despite all its qualities: high structure resistance, insulation, and flexibility, which allow shaping large spans, curves, and adapting to complex geometric spaces.

Serious quakes have affected Colombia in the last decades; the aftermath was a large amount of damaged or collapsed structures. Destruction is caused by a lack of ductility [1]. A type of indigenous housing is wattle and daub houses, called bahareque houses, which is a cultural and regional tradition. This technique uses wood and guadua [2].

The lumber used in the indigenous houses in Tuchín, Department of Córdoba, Colombia, requires a study of physical and mechanical properties so as to ascertain its structural resistance ability. Most of these households are built using reed unions without any kind of design, which is a high risk for natural disasters [3].

Natural lumber is an abundant organic product in the world and it is widely used for support structures for roofs like roof trusses. Also, temporary elements used during construction processes like formworks and provisional buildings as construction campsites frequently use wood [4]. So as to take advantage of wood's best quality, a process to prior usage is executed: wood seasoning. Even when trees are cut during dry seasons, wood always retains water or sap inside, producing the wood to wear away and drawing the attention of insects and fungi, which are the main cause of deterioration, whether this deterioration happens before, during, or after the house is built. Seasoning starts after the trees are cut, leaving wood in the utmost upright position so as to start treating it promptly. After treatment, heartwood is extracted for the wooden posts; this process is performed manually with tools such as axes, machetes, or any other sharp element suitable for the job. It has to be the most resistant part of the tree to prevent termite infestation. Afterwards, the final section of the extracted wood is submerged in water for 4 to 6 hours with the intention of providing greater resistance to it. Finally, the last treatment procedure is carried out, and in this way, the posts that will be used for the house's main structure is ready [5].

Lumber process starts by cutting the trees and transporting them to a sawmill, where they are cut in different pieces to start the wood seasoning. Drying can be a natural process or through the use of ovens built for this purpose called kilns. Then, the immunization process is performed coating the wood with acetic acid; this process extends it useful life [6].
The lumber to be used in construction as roof trusses, formworks, beams, scaffolds, and more, must have high rupture resistance properties MOR and modulus of elasticity -MOE during static bending, as well as maximum compression stress, Proportional Limit Effort -PLE in perpendicular compression, and a high shear stress [7]. At its natural state, wood has the singularity of being directly related to its resistance, hence, the more density, the higher MOE and MOR [8]. Similar moisture content to the place where it will remain is necessary; this guarantees its dimensional stability and reduces the risk of fungi and insect infestation. Lumber also requires a low crackle tendency during seasoning, low to moderate shrinkage, allow unifications using nails, screws, or connectors, large dimensions, and finally, if lumber is in an environment that fosters insect infestation or putrefaction, natural durability needs to be considered and proceed accordingly, this is, treat the wood with a preserving component before use [9]. Wood has three different properties in three different directions perpendicular to each other, and has only three planes perpendicular to each other as well; these define the symmetry of the material's properties [10].

\section{Material and Methods}

Wood is a vegetal composite of vertically-oriented cellulose fibers parallel to the tree's trunk. As the tree widens, new layers of cells are added around the center. This condition of radial growth in rings of different thickness makes the mechanical properties of wood anisotropic, this is, different in two perpendicular directions: Longitudinal and transversal [11]. Also, layers shown in Fig. 1 constitute the material: phloem, xylem, heartwood, and pith [12].

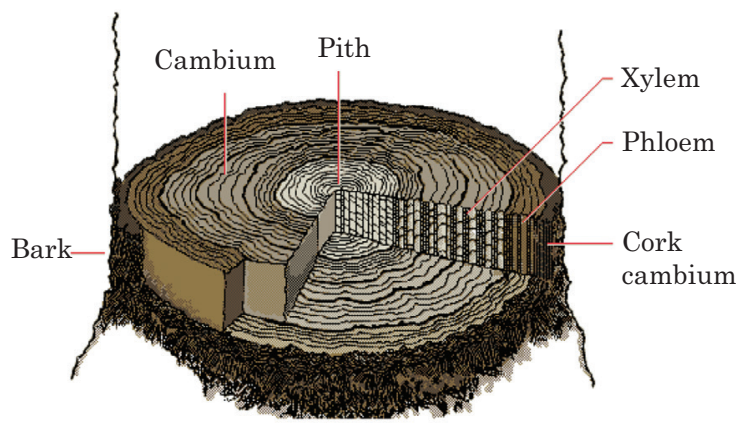

Fig. 1. Parts of wood Source: Encarta Encyclopedia

Wood is ideal for tension stress due to its special directional structure; maximum resistance is achieved when stress is parallel to fiber, when 
perpendicular, resistance reduces. Short or interrupted fibers and knots play an important role for tension forces since resistance reduces. Bending effort originates a tension and a compression effort separated by a neutral region, hence, bending stress is maximum when the acting force is perpendicular and minimum when both are parallel [13].

On the inside, bark is constituted by phloem; a living tissue specialized in transporting elaborated sap. And on the outside, rhytidome or dead bark covers the trunk.

Wood has very convenient features as a structural material, just as it has been used since the beginnings of civilization. Contrary to most construction materials, tensile stress is higher when compared to compression stress, though the latter is also acceptably high. Resistance, lightness, and renewable nature constitute the main qualities for structural usage. Wood features differ according to the tree's specie, origin, and even for the same species, the conditions of the growing place influence. If the coinciding axis of the trunk's longitude is called axial and the axis perpendicularly crossing the pith or medulla is called transverse, axial resistance is 20 to 200 times higher than transverse resistance.

Wood's density varies notably between species. Once dry, some species like Cecropia adenopus barely reach $300 \mathrm{~kg} / \mathrm{m}^{3}$, whereas others can surpass $1200 \mathrm{~kg} / \mathrm{m}^{3}$ - Schinopsis balansae. However, most species range from 500 to $800 \mathrm{~kg} / \mathrm{m}^{3}$ (in dry weight). Density may also fluctuate within the same species, or even in the same tree, depending on the trunk's height and the distance to the pith [15].

Wood is a noble material because of its many usage possibilities, resistance, durability, and malleability. It has a high stress-weight ratio, low thermic and electric conductivity, it is flexible, it keeps its advantages at low temperatures, resists substantial overloads for short periods of time and the action of corrosive chemical agents, and few materials cost less per weight unit than wood [16].

Regarding their growth, wood can be divided into:

- Resinous wood. Slow-growing trees from cold or temperate regions. They have good mechanical stress and are malleable enough to be worked. Some common species are: Pine, fir, and larch.

- Hardwood or wood from broad-leaved trees that grow in temperate regions: Oak, holm oak, beech, chestnut, birch, black poplar, walnut, cherry, apple, and olive.

- Exotic wood. The finest wood which enable the best finishings. Within this group are: Mahogany, ebony, teak, and rosewood [17].

Structure defects are originated within the structure itself during development. The main flaws are:
- Knots. They form when branch rests are embedded by wood as the tree's diameter widens. Consequences are reflected on mechanical stress, mainly in flexion. Also, work becomes difficult, planning wood for instance.

- Shakes. When a transversal cut is performed, ring shakes appear as a tangential separation of the wood fibers along some sections of the rings

- Eccentric pith. In this case, off-center piths or medullas can be observed in a transverse cut. When trees are exposed to strong winds with constant direction, or when trees seek light, the axis is displaced. This defect has consequences when sawn.

- Reaction wood. Refers to the wood present in curved trees or in areas located near thick branches. It can be considered compression wood when mechanical properties are affected, and tension wood when due to its moisture content, it warps during seasoning and mechanical properties also distort, especially in compression parallel to grain.

- Juvenile heartwood. For fast-growing trees, wood has lower apparent specific gravity to that proper of the species. Warp is common when seasoning [18].

Any flaws affecting physical, chemical, and mechanical properties of a wood piece is considered as a defect. For sawn wood, regardless the purpose of use, it is crucial to limit the presence, type, shape, size, and location of defects so as to guarantee its broad and adequate usage [19].

Historically, lumber has been one of the most used materials. Currently, most of the developed countries value it as a structural material using it in more than $90 \%$ of 1 to 4 -story buildings considering that, as abovementioned, wood has many advantages for many purposes [20].

To carry out this analysis, first wood usage as a construction material was studied by way of its cultural adoption for bahareque houses in indigenous communities [21]; then, empirical information was gathered related to the applications given to different kinds of wood with the aim of creating a complete database and contributing with practical evidence to theoretical and numerical data.

The criteria for the selection of wood types were: adequate phytosanitary conditions and acquirement ease.

Logs were attained from each tree and sawn using the circular saw to make precise cuts. After sawn and planned, the pieces were cut with a bandsaw into the necessary dimensions. Electric tools are more powerful than manual, and although they require less effort from the operator, usage risks increase. Today, most of the tools used are electric [22].

Wood types used in the research are classified in Table I. 
Table I. Wood Classification: Scientific Name and Group

\begin{tabular}{|c|c|c|}
\hline Wood & Scientific Name & Group \\
\hline Panama tree & Sterculia apetala & B \\
\hline Saman & Samanea saman & B \\
\hline Mango & Mangifera indica & C \\
\hline Tulpay & Clarisia racemosa & A \\
\hline Oak & Tabebuía rosea & B \\
\hline Teak & Tectona grandis & C \\
\hline
\end{tabular}

Source: Authors

The study of mechanical and physical properties constitutes an objective and fundamental ground to define the possible applications of a specific wood. For this purpose, tests must be executed to small flawless wood samples and in accordance with the established standards.

The properties considered were: moisture content, anhydrous density, basic density, basic specific gravity, total and partial shrinkage -radial, tangential, and volumetric, parallel and perpendicular compression stress, and thermal expansion coefficient. Additionally, wood usage was registered.

For every use identified in the previous methodological stages, the physical properties enabling them were recognized. Tests were executed according to the technical specifications of the ASTM D-143-09 standards, especially designed for small clear specimens of lumber [23]. In order to attain and prepare an adequate test material to be used in the different tests, the procedures prescribed in the ASTM- D 5536-04 standard. Test specimens should be properly coded or marked so as to keep a suitable record, in this way, a sample can be identified at any moment. The code must be simple and clearly written on one side with an appropriate size, preferably using indelible ink [24].

Physical properties as moisture content in green and anhydrous state, density, basic specific gravity, and shrinkage were established by electric stove seasoning. The protocol developed in the project set the temperature at $103^{\circ} \mathrm{C}-105^{\circ} \mathrm{C}$ for a 24 -hour period without any subsequent intervals to avoid specimen incineration until samples achieved a permanent weight. To determine these properties, five to ten clear specimens from at least five different species from Tuchín needed to be prepared -20 to 25 samples in total, as shown in Fig. 2. Specimens ought to have the dimensions stipulated in the ASTM D 143-09 standard; this is, $2.5 \mathrm{~cm} \times 2.5 \mathrm{~cm} \times$ $10 \mathrm{~cm}$. For the study of every condition and species, the same amount of samples is needed.

For each specimen, weight, volume, and dimensions are to be determined for three conditions: at a green state, at $12 \%$ moisture content, and at an anhydrous state ( $0 \%$ moisture content). A 0.01 gram precision digital weighing scale, a $0.01 \mathrm{~mm}$ precision calibration gauge, and an electrical oven are necessary.

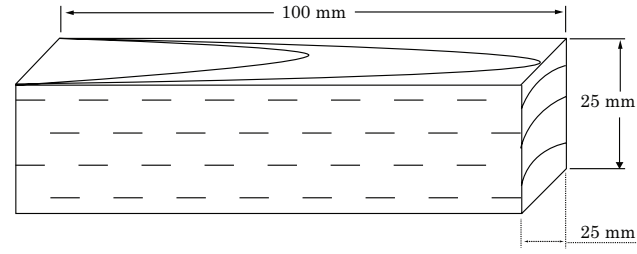

Fig. 2. Specimen for physical property test. Fuente: [26].

Besides this, the thermal expansion coefficient is taken into account because many materials expand when temperature rises. The linear expansion coefficient measures the difference in length corresponding to a temperature change. For this, the original length at the initial temperature and the final length with the concluding temperature are measured. With this information, the linear expansion coefficient can be determined [25].

Nowadays, a concern towards the protection and care of the environment without undermining the progress of urban spaces is evident. The measure scale to safeguard the environment is defined by what is known as sustainability, which seeks to follow guidelines in the different aspects of daily life to achieve a sustainable development in human processes. This includes the implementation of greener options in different aspects; low-carbon emission cars, recyclable and reusable elements, industrial processes and housing designs that consume less energy, or even better, facilities using renewable energy sources are examples of eco-friendly solutions. Construction is not excluded; on the contrary, it is one of the fields that impact the most the environment due to the great amount of elements used, not only during the execution process but also throughout its useful life. Architectural projects and constructions of any kind can substantially alter and impact the environment, for this reason, permanent studies with sustainable criteria are developed in pursuit of an optimum design for buildings. Lumber, as a structural component of buildings, presents a series of potential advantages: lightness in designs, insulation quality, fire resistance, and high sustainable standards in contrast to other structural materials [26].

Usually, preventive protection in lumber is adopted to avoid the attack of biotic agents while a suitable building design results best to prevent damages from aggressive agents like meteorological elements. As it has been mentioned, concrete and steel are the most used materials for construction in cities, leaving wood to minor structural applications and finishings [27], maybe caused by the inconveniences the aforementioned agents may bear.

Wood absorbs and releases moisture until the equilibrium moisture content is achieved, in which inner and outer moisture surrounding the tree is equaled [28]. 
a. Wood in the History of Colombia and Other Regions. The technique of bahareque is typical of the American continent. Among the different types of bahareque are: embedded, rush matting, and woven. Caribbean communities from Colombia and Venezuela shaped their housing with natural materials as follows: wooden pilings serving as structure for a dual-pitched roof made with the palm of the region. For walls and divisions, a guadua rush matting formwork stuffed with a mortar of diverse organic materials was used and compacted with ramming tools; the final layer was covered with a type of lime for decorative purposes. Their patterns always outlined rectangular shapes, and the inner furnishing was completely elaborated with the materials found about.

Bahareque has served as a construction material in Colombia throughout many centuries. First adopted by indigenous people, it was the primary option for European colonists or mestizos who adapted the bahareque technique to the environmental conditions taking advantage of the traditional procedures and the diverse materials found in the region. Later, many bahareque houses were replaced using adobe or rammed earth, though bahareque continued as the favorite technique in areas like the coffee region due to its high seismic risk where still nowadays gigant reed-based bahareque is used, sometimes combined with rammed earth, adobe, and stone or brick bases so as to add stiffness to the structure [29].

Mechanical properties of wood ascertain the ability to withstand external forces. Any demand load or stress acting on the outside and changing the size or dimension of a material is called an external force [30].

b. Location of the Research Project. The research was performed in the urban area of Tuchín's municipality, Department of Córdoba, Colombia, with the aim of detecting the physical and mechanical properties of the materials adopted for indigenous housing considering that this type of dwellings constitute part of the national cultural heritage as well as the contribution this document can provide today to the Zenú indigenous community. Tuchín's coordinates for latitude and longitude are $9^{\circ} 08^{\prime} 57^{\prime \prime} \mathrm{N}$ and $57^{\circ} 30^{\prime} 44^{\prime \prime} \mathrm{W}$. This low-latitude location corresponds to a torrid inter-tropical zone, in consequence, instead of four seasons, only rainy and dry seasons shape the climate [31].

c. Standards Application. Under the specifications provided in Annex J of the NTC 2500 Standard, the visual defect classification of the selected material was performed. The visual classification aims at sorting sawn wood for structural purposes; any irregularity in the physical condition of wood affects its physical and mechanical properties. The main objective is to limit defect's presence, type, shape, size, and location in order to attain suitable lumber for structural usage with the minimum requirements guaranteed [32].
Additionally, the general guidelines established in the NSR 10 Standard regarding the material's quality so as to be used in structures are also taken into account. Lumber for structural purposes ought to have ample natural durability or be adequately preserved. Equally important, all available resources should be applied with the intention of safeguarding it from aggressive agents through a suitable building design or from other types of agents like fungi, insects, or humidity excess [33].

d. Mechanical Properties Determination. Tests refer to compression parallel to fiber and compression perpendicular to fiber. Compression tests, as shown in Fig. 3, are carried out using ASTM D-143-09 Standard specifications "Standard Test Methods for Small Clear Specimens of Timber". For these tests, a $150 \mathrm{kN}$ (30,000 lbf) capacity combination machine was applied; for compression test a deflectometer was used to gather the required data for MOE and MOR estimation.

e. Compression Parallel to Grain. For this test, 5 $\mathrm{cm}$ × $5 \mathrm{~cm}$ x $20 \mathrm{~cm}$ specimens were prepared; 5 per species. Load was applied transversely at a steady speed of $0.3 \mathrm{~mm} / \mathrm{min}$. MOR was estimated using the gathered data.

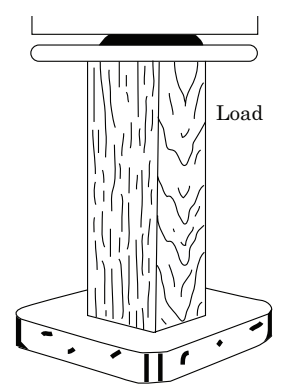

Fig. 3. Specimen for compression parallel to grain test. Source: [26].

f. Compression Perpendicular to Grain. For this test, $5 \mathrm{~cm} \times 5 \mathrm{~cm} \times 15 \mathrm{~cm}$ specimens were prepared. Load was applied through the radial section at a permanent speed of $0.3 \mathrm{~mm} / \mathrm{min}$ using a $5 \mathrm{~cm} \times 5 \mathrm{~cm}$ metallic plate, as shown in Fig. 4 . Depending on material's availability, minimum 5 specimens are to be treated.

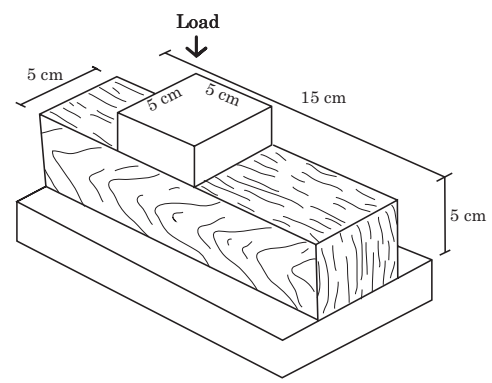

Fig. 4. Specimen for compression perpendicular to grain test. Source: [26]. 
Modulus of elasticity, shear modulus, and Poisson's ratio represent the elasticity features of a material. Wood has three moduli of elasticity, three shear moduli, and six Poisson's ratios oriented and defined in accordance with the three orthogonal axes. From an engineering stance, it can be assumed that the material is homogenous; hence, only three are to be considered.

g. Poisson's modulus or ratio. When a specimen experiments an axial load, the cross-section strain is proportional to the parallel strain. The proportion between transverse and axial strains is called Poisson's ratio $(\mu)$; an elasticity constant provided by the measurement of a section's shrinkage or expansion of an isotropic, linear elastic material when stretched (transverse section reduces) or compressed (transverse section expands). Usually, Poisson's ratio ranges between 0.325 and 0.4 [34].

Compression test specified by the NTC 4025 Standard was executed to cylindrical specimens --15 $\mathrm{cm}$ diameter and $30 \mathrm{~cm}$ height [36].

The reference sample was an oak specimen $(5 \mathrm{~cm}$ diameter and $10 \mathrm{~cm}$ height), keeping the standard's proportion $1 / 2$ (diameter/length) until fracture so as to determine stress and strain, as illustrated in Fig. 5. Equally, $15 \mathrm{~cm}$ x $30 \mathrm{~cm}$ oak specimens were taken to obtain cylinders from its core following the direction of the three orthogonal axes to perform the compression parallel to fiber test.

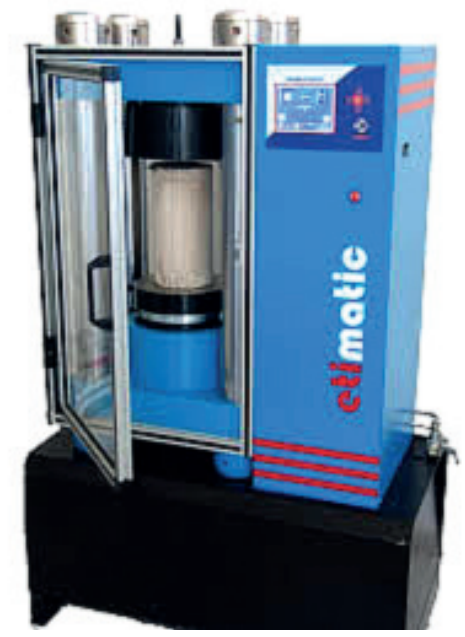

Fig. 5. Cylinder for Poisson's ratio test. Source: Producción de Equipos Técnicos e Industriales, S. A.

h. Shear Modulus or Stiffness. Represents the ratio of shear stress to the shear strain. Although different values exist for each direction -due to its anisotropic nature, the most common represent those aligned with the fibers. These values range from $1 / 16$ to $1 / 25$ from that corresponding to the linear modulus of elasticity found in the same specimen [36].
To establish shear stress parallel to grain, specimens should be cut as observed in Fig. 6. The 'step' or cut seen in the specimen is needed to grasp it to the test machine. According to the ASTM D-143-09 Standard, the area for the load measures $2 \mathrm{~cm} \times 5$ $\mathrm{cm}$ and its speed must be $0.6 \mathrm{~mm} / \mathrm{min}$.

Shear modulus (Table II) is present in most of the uses related to wood and it is classified in accordance with the force's direction in relation to the structural planes.

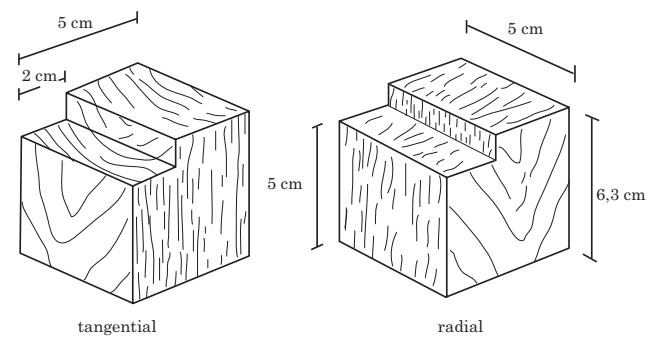

Fig. 6. Specimen for shear parallel to grain test. Source: [26].

Poisson's ratio was attained applying (1):

$$
\mu=\frac{E}{2 G}-1
$$

Table II. Shear Modulus for Wood Categories

\begin{tabular}{|c|c|c|}
\hline \multirow{2}{*}{ Wood } & \multicolumn{2}{|c|}{ Shear Modulus or Stiffness Kg/cm } \\
\cline { 2 - 3 } & Tangential & Radial \\
\hline Panama tree & 62.9 & 57.1 \\
\hline Saman & 94 & 88 \\
\hline Tulpay & 86 & 80 \\
\hline Oak & 84 & 91 \\
\hline
\end{tabular}

Source: Types of Wood in Colombia Universidad Nacional de Colombia-Sena

\section{III.RESUlts AND Discussion}

NTC 2500 Standard "Civil Engineering and Architecture Use of Wood in Construction" establishes that wood should be classified according to commerce practices, industrialization, usage, and moisture content (Table III).

Likewise, volume shrinkage coefficients (Table IV) and radial and tangential shrinkage (Table V) need to be accounted for.

Table III. Moisture Determination for Wood Classification

\begin{tabular}{|l|l|}
\hline \multicolumn{1}{|c|}{ Moisture Content } & Classification \\
\hline $\begin{array}{l}\text { Above }(\mathrm{CH} \%>30 \%) \text { PSF } \\
18 \%-30 \%(\mathrm{PSF}) \\
<18 \%\end{array}$ & Green wood \\
\hline
\end{tabular}

Source: [37] 
Table IV. Shrinkage Coefficient in Volume (\%) FOR WoOd Classification

\begin{tabular}{|c|l|}
\hline Shrinkage Coefficient in Volume \% & \multicolumn{1}{|c|}{ Type of Wood } \\
\hline Less than 0.35 & Low shrinkage \\
0.36 to 0.55 & Moderate shrinkage \\
0.56 to 0.75 & High shrinkage \\
0.76 to 1.00 & Very high shrinkage \\
\hline
\end{tabular}

Source: [37]

Table V. Radial and Tangential Shrinkage for Wood Classification

\begin{tabular}{|c|l|}
\hline T/R (\%) & \multicolumn{1}{|c|}{ Type of Wood } \\
\hline Less than 1.5 & High dimensional stability \\
1.5 to 1.8 & Moderate dimensional stability \\
More than 1.8 & Low dimensional stability \\
\hline
\end{tabular}

Source: [37]

With the intention of grouping wood by structural uses (Tables VI, VII, VIII), basic density is used as indicator of mechanical properties, thus:

- Group A: Wood with basic density above $0.71 \mathrm{~g} / \mathrm{cm}^{3}$

- Group B: Wood with basic density between 0.56 and $0.70 \mathrm{~g} / \mathrm{cm}^{3}$

- Group C: Wood with basic density between 0.4 and $0.55 \mathrm{~g} / \mathrm{cm}^{3}$

Table Vi. Specific Weight for Wood Classification

\begin{tabular}{|l|l|}
\hline \multicolumn{1}{|c|}{ Classification } & Specific Weight \\
\hline Light wood & $<0.40$ \\
Moderately heavy wood & $0.40-0.75$ \\
Heavy wood & $>0.75$ \\
\hline
\end{tabular}

Source: [38]

Table VII. Classification Regarding

Compression Stress Parallel to Grain

\begin{tabular}{|l|l|}
\hline \multicolumn{1}{|c|}{$\begin{array}{c}\text { Compression Stress Parallel to Grain } \\
\text { Classification }\end{array}$} & \multicolumn{1}{|c|}{$\left(\mathbf{k g} / \mathbf{c m}^{\mathbf{2}}\right)$} \\
\hline Very low & $<200$ \\
Low & $201-300$ \\
Moderate & $301-400$ \\
High & $401-500$ \\
Very high & $>500$ \\
\hline
\end{tabular}

Source: [37]

Table VIII. Classification Regarding Compression Stress Perpendicular to Grain

\begin{tabular}{|l|l|}
\hline \multicolumn{1}{|c|}{$\begin{array}{c}\text { Compression Stress Perpendicular to } \\
\text { Grain Classification }\end{array}$} & \multicolumn{1}{|c|}{$\left(\mathbf{k g} / \mathbf{c m}^{2}\right)$} \\
\hline Very low & $<25$ \\
Low & $26-50$ \\
Moderate & $51-75$ \\
High & $76-100$ \\
Very high & $>100$ \\
\hline
\end{tabular}

Source: [37]
From the results obtained, Table IX shows moisture content for Panama tree is $<18 \%$ (PSF), which classifies this wood as commercially dry with very high volumetric shrinkage (1.72\%) meaning an important dimensional change; regarding $\mathrm{T} / \mathrm{R}$ correspondence, it is classified as a very stable dimensionally.

According to basic density, ranging between 0.56 and $0.70 \mathrm{~g} / \mathrm{cm}^{3}$, Panama tree is classified in group $\mathrm{B}$, which comprises wood types of moderate stress suggested for structural parts or pieces of certain magnitude known as semi-heavy structures.

Specific weight indicates Panama tree is reasonably heavy; and compression stress parallel to grain is moderate whereas compression stress perpendicular to grain is high.

Table IX. Physical And Mechanical Properties Outcome For Panama Tree

\begin{tabular}{|c|c|c|c|}
\hline Properties & Unit & Nomenclature & Average \\
\hline Moisture Content & $(\%)$ & & 9,38 \\
\hline \multirow{2}{*}{ Density } & \multirow{2}{*}{$\left(\mathrm{g} / \mathrm{cm}^{3}\right)$} & Basic & 0,58 \\
\hline & & at $12 \% \mathrm{MC}$ & 0,60 \\
\hline Specific Weight & & Basic & 0,73 \\
\hline \multirow{5}{*}{ Shrinkage } & \multirow{5}{*}{$(\%)$} & Longitudinal & 0,22 \\
\hline & & Tangential & 0,71 \\
\hline & & Radial & 0,79 \\
\hline & & Volumetric & 1,72 \\
\hline & & $\mathrm{T} / \mathrm{R}$ & 0,90 \\
\hline \multirow{3}{*}{$\begin{array}{l}\text { Compression } \\
\text { Parallel to Grain }\end{array}$} & \multirow{3}{*}{$\left(\mathrm{Kg} / \mathrm{cm}^{2}\right)$} & PLE & 176,96 \\
\hline & & MOR & 348,11 \\
\hline & & MOE X10 $0^{3}$ & 31,16 \\
\hline $\begin{array}{c}\text { Compression } \\
\text { Perpendicular to Grain }\end{array}$ & $\left(\mathrm{Kg} / \mathrm{cm}^{2}\right)$ & PLE & 348,11 \\
\hline $\begin{array}{c}\text { Thermal Expansion } \\
\text { Coefficient }\end{array}$ & $\left({ }^{\circ} \mathrm{C}^{-1}\right)$ & (a) & $3.03 \times 10^{-5}$ \\
\hline \multirow{2}{*}{ Poisson's Ratio } & & Tangential & 0,40 \\
\hline & & Radial & 0,54 \\
\hline
\end{tabular}

Source: Authors

From the results obtained, Table $\mathrm{X}$ shows moisture content for Saman is $<18 \%$ (PSF), which classifies this wood as commercially dry with very high volumetric shrinkage (1.90\%) meaning an important dimensional change; regarding T/R correspondence, it is classified as very stable dimensionally.

According to basic density, ranging between 0.56 and $0.70 \mathrm{~g} / \mathrm{cm}^{3}$, Saman is classified in group B, which comprises wood types of moderate stress suggested for structural parts or pieces of certain magnitude known as semi-heavy structures.

Specific weight indicates Saman is reasonably heavy; and compression stress parallel to grain is moderate whereas compression stress perpendicular to grain is high. 
Table X. Physical and Mechanical Properties Outcome for Saman

\begin{tabular}{|c|c|c|c|}
\hline Properties & Unit & Nomenclature & Average \\
\hline Moisture Content & (\%) & & 12,14 \\
\hline \multirow{2}{*}{ Density } & \multirow{2}{*}{$\left(\mathrm{g} / \mathrm{cm}^{3}\right)$} & Basic & 0,57 \\
\hline & & at $12 \% \mathrm{MC}$ & 0,55 \\
\hline Specific Weight & & Basic & 0,46 \\
\hline \multirow{5}{*}{ Shrinkage } & \multirow{5}{*}{ (\%) } & Longitudinal & 0,32 \\
\hline & & Tangential & 0,79 \\
\hline & & Radial & 0,79 \\
\hline & & Volumetric & 1,90 \\
\hline & & $\mathrm{T} / \mathrm{R}$ & 1,00 \\
\hline \multirow{3}{*}{$\begin{array}{l}\text { Compression } \\
\text { Parallel to Grain }\end{array}$} & \multirow{3}{*}{$\left(\mathrm{Kg} / \mathrm{cm}^{2}\right)$} & PLE & 255,76 \\
\hline & & MOR & 318,33 \\
\hline & & $\mathrm{MOE} \times 10^{3}$ & 75,26 \\
\hline $\begin{array}{l}\text { Compression } \\
\text { Perpendicular to } \\
\text { Grain }\end{array}$ & $\left(\mathrm{Kg} / \mathrm{cm}^{2}\right)$ & PLE & 210,31 \\
\hline $\begin{array}{c}\text { Thermal Expansion } \\
\text { Coefficient }\end{array}$ & $\left({ }^{\circ} \mathrm{C}^{-1}\right)$ & (a) & $7,28 \times 10^{-5}$ \\
\hline \multirow{2}{*}{ Poisson's Ratio } & & Tangential & 0,36 \\
\hline & & Radial & 0,45 \\
\hline
\end{tabular}

Source: Authors

From the results obtained, Table XI shows moisture content for Mango is between 18-30\% (PSF), which classifies this wood as semi-seasoned with very high volumetric shrinkage (1.89\%) meaning an important dimensional change; regarding $\mathrm{T} / \mathrm{R}$ correspondence, it is below $1.5 \%$, hence, classified as very stable dimensionally.

According to basic density, ranging between 0.4 and $0.55 \mathrm{~g} / \mathrm{cm}^{3}$, Mango is classified in group $\mathrm{C}$, which comprises wood types of less stress suggested for utilitarian purposes in construction, where stress and malleability combine, including manufacturing activities like hammering, cutting, assembling, etc.

Specific weight indicates Mango is reasonably heavy; and compression stress parallel to grain is high just as compression stress perpendicular to grain.

From the results obtained, Table XII shows moisture content for Tulpay is between $18-30 \%$ (PSF), which classifies this wood as semi-seasoned with very high volumetric shrinkage (1.74\%) meaning an important dimensional change; regarding $\mathrm{T} / \mathrm{R}$ correspondence, it is below $1.5 \%$, hence, classified as very stable dimensionally.

According to basic density, above $0.70 \mathrm{~g} / \mathrm{cm}^{3}$, Tulpay is classified in group A, which comprises wood types of the highest stress suggested for heavy duty construction and port and marine usage, where resistance and durability are the most important factors and malleability is not necessary.
Table Xi. Physical and Mechanical Properties Outcome for Mango

\begin{tabular}{|c|c|c|c|}
\hline Properties & Unit & Nomenclature & Average \\
\hline Moisture Content & $(\%)$ & & 21,29 \\
\hline \multirow{2}{*}{ Density } & \multirow{2}{*}{$\left(\mathrm{g} / \mathrm{cm}^{3}\right)$} & Basic & 0,48 \\
\hline & & at $12 \% \mathrm{MC}$ & 0,57 \\
\hline Specific Weight & & Basic & 0,63 \\
\hline \multirow{5}{*}{ Shrinkage } & \multirow{5}{*}{$(\%)$} & Longitudinal & 0,14 \\
\hline & & Tangential & 0,80 \\
\hline & & Radial & 0,95 \\
\hline & & Volumetric & 1,89 \\
\hline & & $\mathrm{T} / \mathrm{R}$ & 0,84 \\
\hline \multirow{3}{*}{$\begin{array}{l}\text { Compression } \\
\text { Parallel to Grain }\end{array}$} & \multirow{3}{*}{$\left(\mathrm{Kg} / \mathrm{cm}^{2}\right)$} & PLE & 213,98 \\
\hline & & MOR & 421,32 \\
\hline & & MOE X $10^{3}$ & 33,21 \\
\hline $\begin{array}{l}\text { C o m p ress i o } n \\
\text { Perpendicular to } \\
\text { Grain }\end{array}$ & $\left(\mathrm{Kg} / \mathrm{cm}^{2}\right)$ & PLE & 312,79 \\
\hline $\begin{array}{l}\text { Thermal Expansion } \\
\text { Coefficient }\end{array}$ & $\left({ }^{\circ} \mathrm{C}^{-1}\right)$ & (a) & $1,19 \times 10^{-4}$ \\
\hline \multirow{2}{*}{ Poisson's Ratio } & & Tangential & (n...... \\
\hline & & Radial & n...... \\
\hline
\end{tabular}

Source: Authors

Specific weight indicates Tulpay is reasonably heavy; and compression stress parallel to grain is high just as compression stress perpendicular to grain.

Tabla XII. Physical and Mechanical

Properties Outcome for Tulpay

\begin{tabular}{|c|c|c|c|}
\hline Properties & Unit & Nomenclature & Average \\
\hline Moisture Content & $(\%)$ & & 20,27 \\
\hline \multirow{2}{*}{ Density } & \multirow{2}{*}{$\left(\mathrm{g} / \mathrm{cm}^{3}\right)$} & Basic & 0,73 \\
\hline & & at $12 \% \mathrm{MC}$ & 0,67 \\
\hline Specific Weight & & Basic & 0,59 \\
\hline \multirow{5}{*}{ Shrinkage } & \multirow{5}{*}{$(\%)$} & Longitudinal & 0,38 \\
\hline & & Tangential & 0,72 \\
\hline & & Radial & 0,64 \\
\hline & & Volumetric & 1,74 \\
\hline & & $\mathrm{T} / \mathrm{R}$ & 1,13 \\
\hline \multirow{3}{*}{$\begin{array}{l}\text { Compression } \\
\text { Parallel to Grain }\end{array}$} & \multirow{3}{*}{$\left(\mathrm{Kg} / \mathrm{cm}^{2}\right)$} & PLE & 259,25 \\
\hline & & MOR & 411,97 \\
\hline & & MOE X $10^{3}$ & 54,65 \\
\hline $\begin{array}{l}\text { Compression } \\
\text { Perpendicular to } \\
\text { Grain }\end{array}$ & $\left(\mathrm{Kg} / \mathrm{cm}^{2}\right)$ & PLE & 423,35 \\
\hline $\begin{array}{l}\text { Thermal Expansion } \\
\text { Coefficient }\end{array}$ & $\left({ }^{\circ} \mathrm{C}^{-1}\right)$ & (a) & $3,28 \times 10^{-5}$ \\
\hline \multirow{2}{*}{ Poisson's Ratio } & & Tangential & 0,50 \\
\hline & & Radial & 0,62 \\
\hline
\end{tabular}

Source: Authors 
From the results obtained, Table XIII shows moisture content for Oak is between 18-30\% (PSF), which classifies this wood as semi-seasoned with very high volumetric shrinkage $(2.66 \%)$ meaning an important dimensional change; regarding $\mathrm{T} / \mathrm{R}$ correspondence, it is classified as very stable dimensionally.

According to basic density, ranging between 0.56 and $0.70 \mathrm{~g} / \mathrm{cm}^{3}$, Oak is classified in group B, which comprises wood types of moderate stress suggested for structural parts or pieces of certain magnitude known as semi-heavy structures.

Specific weight indicates Oak is reasonably heavy; and compression stress parallel to grain is moderate whereas compression stress perpendicular to grain is high.

Table XiII. Physical And Mechanical Properties Outcome for Oak

\begin{tabular}{|c|c|c|c|}
\hline Properties & Unit & Nomenclature & Average \\
\hline Moisture Content & (\%) & & 27,61 \\
\hline \multirow[b]{2}{*}{ Density } & \multirow[b]{2}{*}{$\left(\mathrm{g} / \mathrm{cm}^{3}\right)$} & Basic & 0,54 \\
\hline & & at $12 \% \mathrm{MC}$ & 0,52 \\
\hline Specific Weight & & Basic & 0,53 \\
\hline \multirow{5}{*}{ Shrinkage } & \multirow{5}{*}{ (\%) } & Longitudinal & 0,30 \\
\hline & & Tangential & 1,14 \\
\hline & & Radial & 1,22 \\
\hline & & Volumetric & 2,66 \\
\hline & & $\mathrm{T} / \mathrm{R}$ & 0,93 \\
\hline \multirow{3}{*}{$\begin{array}{l}\text { Compression Parallel } \\
\text { to Grain }\end{array}$} & \multirow{3}{*}{$\left(\mathrm{Kg} / \mathrm{cm}^{2}\right)$} & PLE & 223,20 \\
\hline & & MOR & 317,37 \\
\hline & & MOE X10 & 29,68 \\
\hline $\begin{array}{l}\text { Compression } \\
\text { Perpendicular to } \\
\text { Grain }\end{array}$ & $\left(\mathrm{Kg} / \mathrm{cm}^{2}\right)$ & PLE & 310,35 \\
\hline $\begin{array}{l}\text { Thermal Expansion } \\
\text { Coefficient }\end{array}$ & $\left({ }^{\circ} \mathrm{C}^{-1}\right)$ & (a) & $3,03 \times 10^{-5}$ \\
\hline \multirow{2}{*}{ Poisson's Ratio } & & Tangential & 0,32 \\
\hline & & Radial & 0,22 \\
\hline
\end{tabular}

Source: Authors

From the results obtained, Table XIV shows moisture content for Teak is $<18 \%$ (PSF), which classifies this wood as commercially dry with a very high volumetric shrinkage $3.80 \%$, the highest, meaning an important dimensional change; regarding T/R correspondence, less than $1.5 \%$ it is classified as very stable dimensionally.

According to basic density, ranging between 0.4 and $0.55 \mathrm{~g} / \mathrm{cm}^{3}$, Teak is classified in group $\mathrm{C}$, which comprises wood types of less stress suggested for utilitarian purposes in construction, where stress and malleability combine, including manufacturing activities like hammering, cutting, assembling, etc.
Specific weight indicates Teak is reasonably heavy; and compression stress parallel to grain is moderate whereas compression stress perpendicular to grain is high.

Table XIV. Physical and Mechanical Properties Outcome for Teak

\begin{tabular}{|c|c|c|c|}
\hline Properties & Unit & Nomenclature & Average \\
\hline $\begin{array}{l}\text { Moisture } \\
\text { Content }\end{array}$ & $(\%)$ & & 10,28 \\
\hline \multirow{2}{*}{ Density } & \multirow{2}{*}{$\left(\mathrm{g} / \mathrm{cm}^{3}\right)$} & Basic & 0,55 \\
\hline & & at $12 \% \mathrm{MC}$ & 0,52 \\
\hline Specific Weight & & Basic & 0,55 \\
\hline \multirow{5}{*}{ Shrinkage } & \multirow{5}{*}{$(\%)$} & Longitudinal & 1,27 \\
\hline & & Tangential & 1,30 \\
\hline & & Radial & 1,23 \\
\hline & & Volumetric & 3,80 \\
\hline & & $\mathrm{T} / \mathrm{R}$ & 1,06 \\
\hline \multirow{3}{*}{$\begin{array}{c}\text { Compression } \\
\text { Parallel to } \\
\text { Grain }\end{array}$} & \multirow{3}{*}{$\left(\mathrm{Kg} / \mathrm{cm}^{2}\right)$} & PLE & 248,87 \\
\hline & & MOR & 307,34 \\
\hline & & MOE X $10^{3}$ & 22,57 \\
\hline $\begin{array}{l}\text { Compression } \\
\text { Perpendicular } \\
\text { to Grain }\end{array}$ & $\left(\mathrm{Kg} / \mathrm{cm}^{2}\right)$ & PLE & 271,18 \\
\hline $\begin{array}{l}\text { Thermal Ex- } \\
\text { pansion Coef- } \\
\text { ficient }\end{array}$ & $\left({ }^{\circ} \mathrm{C}^{-1}\right)$ & (a) & $1,48 \times 10^{-4}$ \\
\hline \multirow{2}{*}{ Poisson's Ratio } & & Tangential & 0,20 \\
\hline & & Radial & (n...... \\
\hline
\end{tabular}

Source: Authors

\section{Conclusions}

Finding the modulus of elasticity, shear modulus, and Poisson's ratio in a material such as wood requires that tests are performed in the different axes: transverse, tangential, and radial.

The number of specimens should be increased and non-destructive methods need to be implemented so as to approach the values of mechanical properties of wood.

Bending tests are necessary to determine longitudinal MOR and MOE.

Stress data must be presented with the same moisture content performing a semilogarithmic correction.

Tests for steel bolts connecting wooden structural elements are in order since it is crucial to consider shear, tensile, and compression stress.

More studies regarding this subject are desirable, though more rigor and consistency is necessary. For this, statistical and probabilistic data analyses are suggested. 


\section{REFERENCES}

[1] J. Hernández, "Modelación inelástica dinámica simplificada de edificaciones de concreto reforzado," Puente Rev. Cient., vol. 8, no. 1, pp. 51-60, 2014.

[2] C. Sánchez, "La arquitectura de tierra en Colombia, procesos y culturas constructivas," Apunt. Rev. Cient., vol. 20, no. 2, pp. 242-255, 2007.

[3] Y. Li and B. Ellingwood, "Framework for Multihazard Risk Assessment and Mitigation for Wood-Frame Residential Construction,” J. Struct. Eng., vol. 135, no. 2, pp. 159-168, 2009. DOI:10.1061/(ASCE)07339445(2009)135:2(159)

[4] B. Sandrisser, "Passive and Low Energy Ecotechniques," in Third International PLEA Conference, 1984, pp. $672-681$.

[5] E. Cuartas, J. Hernández, and M. Monroy, "Sistema estructural sostenible medioambientalmente de maloka hecha con madera, bahareque y boñiga de vaca en el municipio de Tuchín, Departamento de Córdoba, Colombia," Rev. Colomb. Cienc. Anim., vol. 6, no. 1, pp. 261-282, 2014.

[6] N. A. Fadl and A. H. Basta, "Enhancement of the dimensional stability of natural wood by impregnates," Pigment Resin Technol., vol. 34, no. 2, pp. 72-87, 2005. DOI:10.1108/03699420510585148

[7] J. Arroyo, Clasificación de Usos y Esfuerzos de Trabajo para Maderas Venezolanas. Mérida: Laboratorio Nacional de Productos Forestales, 1987, p. 3284.

[8] J. S. Barreto Castañeda, "Estudio de propiedades físico mecánicas (corte y flexión) de la especie de madera tropical teca (tectona grandis) en el sistema de laminado pegado estructural," Universidad Nacional de Colombia., 2013.

[9] PROEXPO, Maderas Colombianas. Bogotá: Fondo de promoción de exportaciones, 1970, p. 177.

[10] J. Cruz Benedetti, L. Martínez Acosta, J. Lakah Durango, J. Hernández Ávila, and A. López Ramos, "La Madera como elemento estructural aplicado a la arquitectura con sentido social,” Puente Rev. Cient., vol. 7, no. 1, pp. 87-92, 2013

[11] N. Parra, A. Villazón, and R. Pinzón, Predimensionamiento. Definición de la estructura portante en arquitectura, 1st ed. Bogotá: Universidad de los Andes, 2013.

[12] D. Castejón, "Estructura de la madera," 2014. [En línea]. Disponible en: http://www.maderascastejon.com/estructura.asp.

[13] R. N. Kipes, "Propiedades de la madera," 2014. [En línea]. Disponible en: http://www.arqhys.com/contenidos/madera-propiedades.html.

[14] A. Orbe, J. Cuadrado, E. Rojí, and A. Maturana, Arquitectura y Madera Guía de Diseño de Elementos Estruc turales Adaptada al CTE, 2nd ed. San Sebastian: Eusko Jaurlaritzaren Argitalpen Zerbitzu Nagusia, 2010. p. $1-10$

[15] Corporación Chilena de la Madera, Manual de Construcción de Viviendas en Madera, 1st ed. Chile: Corporación Chilena de la Madera, 2007.

[16] F. S. Merritt, M. Kent Lifton, and J. Ricketts, Manual del Ingeniero Civil, 4th ed. México: McGrawHill, 1999
[17] J. Miller, Casas de Madera, 1st ed. Paraguay: Blume, 1999. p. 6-10.

[18] A. Rojas, Sistemas estructurales en madera, el mueble y la madera, 2008 p. 7

[19] A. V. Correa, La calidad de la madera y sus aplicaciones, 1st ed. Medellín: Universidad Nacional de Colombia -Sede Medellín, 2003.

[20] F. O. Asso, Materiales de construcción, 3rd ed. Granada: Dossat, 1985. p. 119-122

[21] Wikipedia, "Bahareque," 2014. [En línea]. Disponible en: http://es.wikipedia.org/wiki/Bahareque.

[22] J. Garrett, J. L. I. Fernández, P. Ossorio, and F. J. Rodanés, Diseño y Tecnología, 3rd ed. Madrid: Akal, 1995.

[23] American Society for Testing Materials, Standard Methods of Testing Small Clear Specimens of Timber. Philadelphia: ASTM, 1957, p. 149-149.

[24] American Society for Testing Materials, Standard Practice for Sampling Forest Trees for Determination of Clear Wood Properties. Philadelphia: ASTM, 2010.

[25] American Society for Testing Materials, Standard Test Method for Coefficient of Linear Thermal Expansion of Plastics Between $-30^{\circ} \mathrm{C}$ and $30^{\circ} \mathrm{C}$ With a Vitreous Silica Dilatometer. Philadelphia: ASTM, 2008.

[26] O. Messer, "Comportamiento en Flexión de Vigas Laminadas que Incorporan Pino Oregón," Universidad del Bío-Bío, 2007.

[27] R. Doria, Determinación de la resistencia a la compresión paralela a la fibra y módulo de elasticidad del elemento compuesto guadua-concreto utilizando guadua de la región de Córdoba, Universidad Pontificia Bolivariana, 2012

[28] W. Carrazas and A. Rivero, Bahareque: Guía de construcción para sísmica. Francia: CRATerre, 2002.

[29] JUNAC, Manual de diseño para maderas del grupo andino. Lima: Junta del Acuerdo de Cartagena, 2000.

[30] J. C. Lores, Manual de construcción. Lima: Cementos Lima, 2012.

[31] E. Cuartas, Georreferencia y proceso constructivo de las viviendas indígenas hechas en bahareque del casco urbano del municipio de Tuchín, Departamento de Córdoba, Universidad Pontificia Bolivariana, 2014.

[32] ICONTEC, Ingeniería civil y arquitectura: uso de la madera en la construcción, 1st ed. Bogotá: ICONTEC, 1997.

[33] Ministerio de Ambiente Vivienda y Desarrollo Territorial, Reglamento Colombiano de Construcción Sismo Resistente. Bogotá: Gobierno Nacional de Colombia, 2010.

[34] J. Cruz Benedetti, Estructuras básicas para arquitectos, Escuela de Arquitectura y Diseño, 1st ed. Medellín: Universidad Pontificia Bolivariana, 2008.

[35] ICONTEC, Concretos. Método de Ensayo para Determinar el Módulo de Elasticidad Estático y la Relación de Poisson en Concreto a Compresión. ICONTEC, Bogotá, 2006.

[36] O. Rico, Caracterización estructural de ocho especies de maderas, Corporación Universitaria del Sinú, 2003.

[37] J. Vargas, Anatomía y tecnología de la madera. Escuela Técnica Superior Forestal, Cochabamba, p. 119, 1987.

[38] International Association of Wood Anatomists, "List of microscopic features for hardwood identification," IAWA J., vol. 10, no. 3, pp. 219-232, 1989. DOI:10.1002/ fedr.19901011106 